\title{
Cómo se aproximan los artistas contemporáneos al tema de la mujer: En torno a la curaduría Iconografías femeninas
}

How contemporary artists approach the subject of women: around the art exhibition Female iconographies

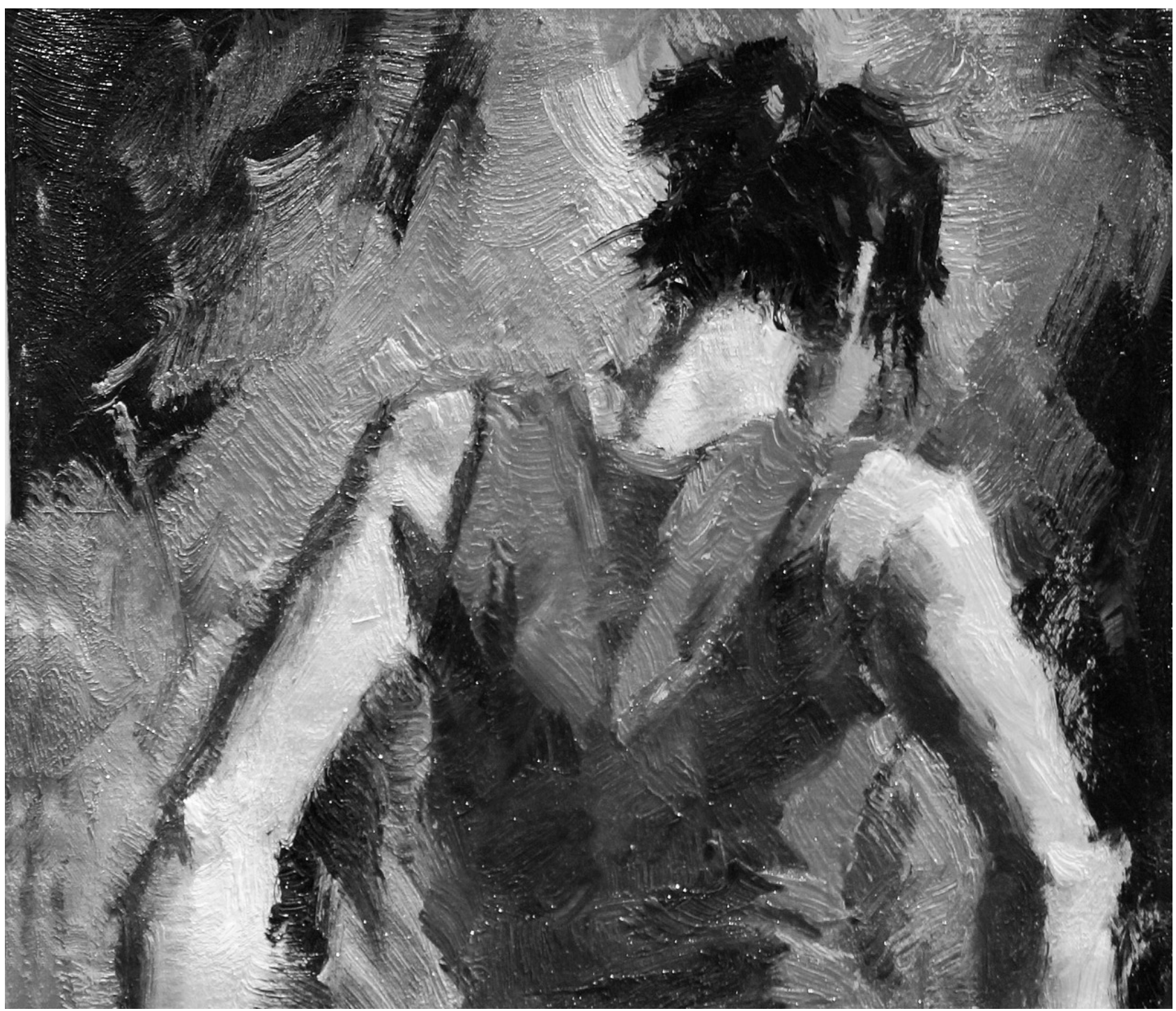




\title{
Cómo se aproximan los artistas contemporáneos al tema de la mujer: En torno a la curaduría Iconografías femeninas ${ }^{1}$ How contemporary artists approach the subject of women: around the art exhibition Female iconographies
}

\author{
José Germán Toloza Hernández²
}

Artículo recibido en marzo 30 de 2019; artículo aceptado en junio 07 de 2019.

Este artículo puede compartirse bajo la Licencia Creative Commons Atribución-No Comercial-Compartir Igual 4.0 Internacional

y se referencia usando el siguiente formato: Toloza, J. (2019). Cómo se aproximan los artistas contemporáneos al tema de la mujer: En torno a la curaduría Iconografías femeninas. I+D Revista de Investigaciones, 14(2), 122-141.

DOI: http://doi.org/10.33304/revinv.v14n2-2019011

\begin{abstract}
Resumen
Históricamente, los artistas han contribuido con sus obras a instaurar un orden patriarcal en las representaciones femeninas usando estereotipos que aún tienden a ser vistos como patrones normales de belleza. El objetivo de este artículo es revisar y analizar cómo están abordando los artistas contemporáneos la figura femenina y el tema de las mujeres. El método utilizado fue conformar una exposición con artistas docentes e investigadores de España, México y Colombia que abordan temas de las mujeres desde visiones y medios diversos. Se hizo una revisión comparativa entre ellas y la historia de las iconografías femeninas. Se identificó cómo los métodos de creación funcionan como herramientas de activismo sociopolítico, alrededor de las violencias de género y la sensibilización. Se concluye que eluden el espectáculo injustificado en sus obras, la importancia que tienen las prácticas culturales comunitarias en espacios marginales y lo autobiográfico, espacios en los que se definen nuevos sentidos de intercambio simbólico.
\end{abstract}

Palabras clave: Arte, contemporáneo, exposición, iconografía, mujer.

\begin{abstract}
Historically, artists have contributed with their works to establish a patriarchal order in female representations, by using stereotypes that still tend to be seen as normal patterns of beauty. The aim of this article is to review and analyze how contemporary artists are addressing the female figure and the issue of women. The method used was the creation of an exhibition with educational artists and researchers from Spain, Mexico and Colombia, who approach the issue of women from different media and perspectives. A comparative review was made between them and the history of feminine iconographies. We identified how the methods of creation function as tools of socio-political activism around gender violence and awareness. We concluded that they avoid the unjustified spectacle in their works, not only the importance of community cultural practices in marginal spaces but also the

1. Artículo de reflexión, de enfoque cualitativo, resultado de un proyecto de investigación en curso, perteneciente al área de bellas artes, subárea de didáctica del arte, desarrollado de forma individual, financiado por la Universidad Industrial de Santander, de la ciudad de Bucaramanga (Colombia). Dirección: carrera 27 calle 9. PBX: 6344000.

2. Magíster en Fine Arts, estudiante de Doctorado en Arte, producción e investigación, Universidad Politécnica de Valencia. Vinculado a la Universidad Industrial de Santander. Bucaramanga (Colombia): Dirección: carrera 27 calle 9. PBX: 6344000. ORCID ID: https://orcid.org/0000-00030986-8036. Correo electrónico institucional: jgtoloza@uis.edu.co.
\end{abstract}


autobiographical aspect, where new meanings of symbolic exchange are defined.

Keywords: Art, contemporary, exhibition, iconography, women.

\section{Introducción}

Lo que subyace es la voluntad de encontrar otras maneras de narrar historias del arte y de la práctica artística de las mujeres diferentes de las que ofrecen los discursos académicos tradicionales y la crítica de arte institucional. Tanto aquellos como esta convergen, según subraya Pollock, "en una serie de ismos definidos por los conceptos de estilo, tendencia, momento y coronados por una figura representativa $y$, de ser posible, genial" (Mayayo, 2015).

Como trasfondo de acción de la curaduría se plantea encontrar líneas, trazos o direccionamientos en la construcción de la figura femenina; es decir, buscar genealogías femeninas en el escenario de nuestras propias identidades y márgenes, ya que muchas son las razones y fuerzas que mueven y definen nuestros itinerarios cotidianos con respecto a las mujeres.

No podemos develar ni sustentar identidades solo desde teorías feministas foráneas, pero sí aproximarnos mediante la contrastación de las producciones artísticas locales, junto a las de otras latitudes, como vías de acceso para empezar a construir genealogías cercanas y coherentes. Solo así, se puede empezar a escribir en contexto, sin tener que perder la perspectiva mundial.

Una curaduría puede entenderse como la puesta en escena de las obras artísticas que han formado parte de un proceso de selección, análisis, exposición y documentación, en el marco de una temática, idea o contexto propuesto por el curador. El proceso curatorial tiene el propósito de permitir la observación y el estudio dentro del contexto conceptual y cultural, pero también de generar lecturas diversas en el espectador. Son de gran valor las relaciones que se establecen entre las obras para propiciar nuevas propuestas curatoriales que den continuidad al tema de interés y aporten elementos a la investigación y la escritura del arte.

La curaduría puede realizarse a partir de un solo artista o un colectivo de artistas. El curador decide qué obras verán los espectadores y también la organización del guion museístico, de manera que hasta cierto punto se pueden anticipar las lecturas. Pero son las tensiones, las concordancias y las disonancias entre las obras las que posibilitarán interpretaciones abiertas y nuevos aportes a la investigación.

Sin embargo, el curador deberá tener un nivel de flexibilidad, precisamente para que las obras puedan respirar también por sí solas, y lograr los alcances investigativos propios que ha alcanzado el artista en el proceso creativo.

La investigación curatorial tiene un efecto directo para la definición del guion curatorial, dado que la misma construcción material de las obras, sus formas y las interpretaciones de contenido repercuten y sugieren los recorridos y la organización temática de estas. Incluso, las identidades de los artistas son importantes y se han de considerar en la puesta en escena, si es el caso. Desde esos elementos, la exposición resultante puede verse como un proceso en transformación en el que surgen diálogos entre imágenes, objetos e identidades.

Como parte del proceso de doctorado, la Universidad Politécnica de Valencia nos permite, dentro de las actividades específicas, realizar curadurías y exposiciones como una forma de poner en relación obras artísticas en torno a una idea, en este caso, sobre las representaciones y simbologías acerca de la figura femenina. En ese diálogo entre las obras se observa que se articulan unas con otras, fundamentando alguna toma de posición sobre las mujeres y sus representaciones, o, por el contrario, visibilizando desencuentros.

Obrist (2009), uno de los más prestigiosos curadores en el mundo, quien ha sido curador de la Serpentine Gallery, en Londres, dice sobre la exposición y la curaduría como investigación:

Si concebimos la exposición como algo abierto, en proceso, la veremos como un complejo sistema de aprendizaje siempre, eso sí, que lleve en sí bucles de retroalimentación que alienten voces de disenso. [...] En otras palabras, deberá permitir que las obras de arte extiendan sus tentáculos hacia otras y que el comisario no se interponga en el camino de esa expansión. La exposición nace cuando lanzas una serie de interrogantes, es decir, una investigación.

Al referirse a la importancia que tiene el término "genealogías" como línea de trabajo para el proyecto 
feminista, Mayayo (2018) cita el concepto de Celia Amorós, según la cual es fundamental recoger, seleccionar y antologizar, lo que significa dar textura a la memoria crítica del feminismo; y esta es una tarea emancipadora.

A la fecha, no se encontraron respuestas con absoluta certeza y de manera generalizada para establecer cuáles son los métodos precisos con los que los artistas contemporáneos solucionan sus formas de aproximación al tema de la mujer y de la figura femenina, por cuanto el campo de la creación artística es tan extenso y diverso como lo es el de las diferencias culturales. Sin embargo, a través de una muestra como la que proporciona la curaduría -con artistas de diferentes nacionalidades-, se puede tener una aproximación para empezar a tejer propuestas válidas e imbricadas en el hacer real, en los contextos cotidianos en que se mueven sus vidas, como artistas, formadores e investigadores; en las diferencias, las asimetrías y los desacuerdos.

Como meta -una vez realizada la curaduría y abierta la exposición al público en la ciudad de Bucaramanga- se propuso revisar y analizar la obra de los artistas invitados y contrastarla en el contexto de ciertos momentos sustanciales en la historia del arte contemporáneo en los que han sobresalido características notables sobre la instauración de modelos y rompimientos en lo que concierne a las mujeres en el arte.

\section{Antecedentes}

La mayoría de los artistas seleccionados para la curaduría Iconografías femeninas ha venido trabajando sobre las representaciones femeninas y temas de las mujeres, o, de alguna forma, han tomado posición frente al tema en los distintos escenarios en que se mueven: creación, docencia, investigación y activismo. Estos artistas también han formado parte de otras exposiciones, cuyo tema en general no necesariamente ha sido el de las mujeres, pero sus obras sí han mantenido dicho interés, es decir, ha sido su enfoque de investigación desde los sesgos particulares que cada cual sigue.

Laura Ribero, desde sus estudios de doctorado en Barcelona, a principios del 2000, asumió en sus fotografías el interés por la condición de las migrantes, a partir de sí misma. Juliana Silva, desde vivencias autorreferenciales, inició, a partir de su profesionalización académica, y en sus exposiciones en Bogotá y Bucaramanga, el interés por analizar las relaciones entre materiales de decoración, cuerpo y política. En los procesos de Andrea Rey y Dinora Palma también ha sido constante la investigación a partir de lo autobiográfico, desde las posibilidades que da el cuerpo en la escultura y el dibujo, respectivamente. El proceso de Mujeres en Espiral fue conocido por el autor de esta investigación durante la estancia en Ciudad de México en 2017, y fue considerado de gran importancia por su enfoque social, político y pedagógico con las mujeres, como aporte a la curaduría desde el arte comunitario, en el seno de la investigación universitaria en la UNAM, desde hace más de diez años. Por su parte, Nadia Granados fue conocida por el autor de esta investigación hace más de cinco años, en una exposición en Bucaramanga; ella realizaba entonces una performance en el museo, desde lo femenino y la incomodidad entre mujer, cuerpo y sexualidad, y ha continuado desde entonces su accionar activista feminista en Colombia, en México y España. Por otra parte, Diana Bama y sus procesos de ecofeminismo a partir del arte urbano, realizados desde su tránsito de Valencia a Ciudad de México, fueron conocidos en Ciudad de México e identificados como fundamentales para dar a la curaduría una variedad de lenguajes en los modos de hacer. Leonardo Caballero comenzó en Bucaramanga; en sus pinturas e intervenciones en el espacio urbano, hace más de seis años, denota su interés por trabajar la figura femenina a partir de las imágenes de las reinas, desde una mirada irónica, en la captura de sus poses, muecas e indumentarias en su aparición en medios. María Isabel Rueda es una artista que lleva casi dos décadas trabajando con el mundo de personajes $B$, o salidos del canon social de la normalidad, los espacios y sus memorias y simbologías. Juan Canales y Carlos Domingo son dos artistas españoles, profesores e investigadores en la Universidad Politécnica de Valencia, a quienes, por su rigor y el interés en sus procesos, se les consideró importantes para esta investigación, por trabajar directamente con obras exclusivas para la curaduría, que se salían de los temas que venían desarrollando durante muchos años entre naturaleza, cuerpo, espiritualidad y arte urbano.

Como se observa, los antecedentes de los artistas invitados señalaron posibilidades formales y conceptuales que en principio respondieron a una posibilidad diversa de modos de hacer, de procedencias para una exposición con muchas posibilidades para la contemplación, y para el análisis de enfoques múltiples sobre las iconografías femeninas.

Ahora bien, las investigaciones sobre estudios de género que analizan la imagen de la mujer en la historia del arte coinciden en varios ejemplos que se convierten en modelos para revaluar las hegemonías representacionales y también para propiciar detonantes de cambio. Por ejemplo, la pintura La Venus de Urbino 
(Tiziano Vecellio, 1538) es tomada como una típica representación de la mujer que mira pasivamente cómo el espectador -que, según Berger (2016) es un observador masculino- contempla su desnudez desde fuera del cuadro.

De otra parte, es evidente que en los grandes museos tradicionales las mujeres aparecen como Venus nacientes del mar, con cuerpos esplendorosos, como frágiles durmientes, como Floras rodeadas de naturaleza o como ingenuas damas juguetonas tomando el baño en el río. Esto es, siempre como frágiles objetos de deseo.

Nead (1992) evalúa la institucionalizada visión de Kenneth Clark y devela que el problema del desnudo femenino estuvo sustentado sobre la idea de un cuerpo idealizado y elevado como experiencia estética, diferenciado de la obscenidad que expele la pornografía explícita. Este cuerpo estetizado, llevado a una categoría privilegiada, se enmarca incluso dentro de un orden patriarcal en el cual la mujer está para ser observada y disfrutada por el hombre, como objeto y no como sujeto, bajo el supuesto de la estética. Para la escritora feminista, es claro que Clark, en sus comentarios sobre el desnudo, asume un desnudo femenino y un espectador, o incluso artista masculino, consumidor del cuerpo femenino (Nead, 1992).

Pollock (2013) analiza la lógica fetichista en las pinturas de Dante Gabriel Rossetti, en las que aparece insistentemente la figura de la poeta y artista Elizabeth Siddal, y obsesivamente se usan flores como una metáfora de la mujer en analogía con sus genitales. Según la escritora, se reconoce y se oculta al mismo tiempo la representación genital en las flores que acompañan regularmente a las Venus en la pintura europea. En otro momento de sus análisis, Pollock también alude a la fijación en Rossetti por la boca de las mujeres en sus cuadros, desde un ángulo psicoanalítico.

Mayayo (2015) expone cómo Degas pinta mujeres que no saben que están siendo miradas, desde una posición omnisciente del hombre, contemplación excitante de lo ilícito que es propio del voyeur, mientras que Mulvey (2007) se refiere a la mirada escopofílica o la pulsión escópica como el placer visual, el deseo de poseer a través de la mirada. Este mismo análisis lo hace en relación con los dibujos de Pablo Picasso, en los cuales el espectador siempre es masculino, y el espectáculo es femenino: él es sujeto, y ella, objeto.

En los años sesenta surge una tendencia de expresión en las formas y temas, la de la iconología vaginal. Mayayo recuerda que en esos años Chicago y Schapiro (1973) iniciaron una investigación en la que contemplaban y evaluaban las obras de artistas amigas en las que creyeron encontrar lugares comunes:

Descubrimos que las mujeres recurrían al empleo de una imagen central, generalmente una flor o una versión de una forma floral, rodeada a veces de pliegues y ondulaciones, como en la estructura de una vagina. Nos encontramos con una abundancia de formas sexuales: pechos, nalgas, órganos femeninos (Mayayo, 2015).

Seguidamente, Mayayo (2015) precisa los peligros del esencialismo: "la glorificación de los órganos sexuales femeninos que emprenden Chicago y Schapiro corre el riesgo de perpetuar la sexualización a la que se han visto tradicionalmente condenadas las mujeres: estas imágenes vaginales se prestan a peligrosos malentendidos".

En los años noventa es fundamental la apropiación que hacen las mujeres de las tecnologías de la información y la comunicación, por cuanto las máquinas digitales estaban muy limitadas al uso masculino. Este acercamiento máquina-mujer activa la creación de redes que permiten y facilitan el empoderamiento de las mujeres sobre los temas del feminismo, la creación de revistas y herramientas pedagógicas de la mano de internet, y también como mecanismo de exploración y expresión artística mediante la apropiación del ciberespacio como vía de resistencia. Con la publicación del Manifiesto cyborg, Haraway (1984) sostiene que frente a la penetración de las informáticas de la dominación en nuestros cuerpos es conveniente, como única salida, apropiarse de este cuerpo militarista y masculino y apropiárselo en beneficio propio y subvertirlo. En palabras de Mayayo (2015), lo que Haraway propone es la emergencia de un cuerpo poshumano, condición que Braidotti (2015) traduce como un signo esperanzador que anuncia el festivo surgir de nuevas posibilidades.

\section{La curaduría Iconografías femeninas}

Se realizó una selección de obras de once artistas de nacionalidad mexicana, española y colombiana, algunos de los cuales no necesariamente están en sus países de origen, sino que se han radicado, estudian o trabajan en otros países. Esos países son Brasil, Canadá, España, México y Colombia.

Las obras ponen el foco en diferentes modos de construcción de la figura femenina, incluso, más allá de su representación, formas de percepción visual, sensorial, emocional y política respecto a la mujer y la 
femineidad. Sin embargo, es prudente aclarar, como sugiere Hustvedt (2017), que las representaciones artísticas estarán muertas si no hay un espectador que establezca una relación especial con la mujer representada y que es imaginada una vez la haga parte de sí: "En otras palabras, nos acercamos a las obras de arte con nuestro Yo y nuestro pasado, que comprende no solo nuestra sensibilidad e inteligencia sino también nuestros prejuicios y puntos débiles".

En sus obras, los artistas plantean reflexiones críticas o interpretaciones personales desde varias aproximaciones: una sociedad de protagonismos estereotipados, reivindicaciones de la mujer en un ámbito cultural de vetos y tipos agazapados de violencia de género. También, posiciones críticas sobre las resignificaciones de lo femenino frente a discursos tradicionales y patriarcales; representaciones personales desde el lente de la ensoñación; lo sobrenatural; el mismo cuerpo de la mujer como problema plástico y autobiográfico; los estereotipos frente a las realidades de poder y manipulación, enfocados desde el sarcasmo o la crudeza posporno; y, por supuesto, la postura de combate frente a la violencia de género.

El cuerpo de la curaduría comienza a definirse por la curiosidad intelectual de conocer cómo los artistas contemporáneos construyen relatos en torno a la figura femenina. Primero, se revisaron personalidades que circulan con gran éxito en las grandes ligas de las galerías, museos y ferias internacionales del arte, como Gilliam Wearing, Martha Rosler, Julian Opie, John Currin, Ghada Amer y Mavi Escamilla, por mencionar solo algunos. Luego, se da la oportunidad de acercarnos y conocer artistas investigadores y pedagogos cuya función es fundamental en las academias latinoamericanas y europeas, artistas que al tiempo están vivenciando y analizando contextos reales, construyendo y haciendo circular sus investigaciones.

Parte de la metodología consiste en seleccionar artistas que se fueron encontrando durante el proceso de investigación, si bien algunos de los procesos artísticos se conocían con anterioridad. Los artistas invitados son Andrea Rey, Juliana Silva, Laura Ribero, Leonardo Caballero, María Isabel Rueda, Nadia Granados, el grupo Mujeres en Espiral, Juan Carlos Domingo, Juan Canales, Diana Bama y Dinora Palma.

En estos artistas confluye la condición de desplazamiento geográfico y mental en el proceso de sus percepciones interculturales sobre el asunto de las iconografías femeninas, lo que resulta fundamental, por las diferentes miradas y perspectivas que ofrecen.
Es importante visualizar mentalmente los contextos en que se mueven y la multiplicidad de lentes y visiones que pueden revelarse desde la conciencia activa sobre escenarios diferentes para los estudios sobre las mujeres.

El título de la exposición, Iconografías femeninas, tiene la intención de aludir a la acción de contemplar y analizar formas y significados en las obras artísticas expuestas sobre la mujer. Por lo anterior, involucra en su análisis entrar en la interpretación iconológica.

Atendiendo a las bases del método iconográfico del historiador inglés Erwin Panofsky (1972), las imágenes se leen como proyecciones de la cultura en tres niveles, lo preiconográfico, lo iconográfico y lo iconológico.

Lo'preiconográfico' lo define Panofsky como el contenido temático natural o primario. Consiste en la identificación de formas puras, la configuración de líneas, colores, masas y materiales. Al referirse a las representaciones de objetos naturales como seres humanos, animales, plantas, etc., se les puede llamar el mundo de los motivos artísticos. En otras palabras, se analizan las obras de arte desde el campo estilístico formal acudiendo a la información elemental.

El nivel 'iconográfico' consiste en relacionar los motivos artísticos con temas y conceptos. Son, según Panofsky, los motivos portadores de significado secundario o convencional, y son llamados imágenes, historias o alegorías. Este nivel nos facilita la lectura de las imágenes al describir las temáticas desde un rebote con lo cultural.

Y, en lo 'iconológico', se ahondó más allá de la forma hacia las ideas que se esconden en los temas y en un contexto cultural específico. Panofsky lo explica como una interpretación exhaustiva del significado intrínseco y de los valores simbólicos. También lo define como una interpretación iconográfica en un sentido más profundo.

Desde esa perspectiva, se propone, a partir de las imágenes dibujísticas, pictóricas, escultóricas, fotográficas o de video, entrar en la interpretación de los contenidos de las obras desde las variaciones y particularidades que nos ofrecen las formas de sus materializaciones, tratando de encontrar esos nexos o divergencias que permitan entender cómo ven, cómo comprenden y cómo quieren significar los artistas los asuntos sobre la mujer a través de la poética del producto artístico.

Con respecto al proceso que implica la lectura de obras artísticas, es pertinente recordar a Mayayo (2015), quien hace un llamado sobre la responsabilidad que subyace 
en dichas obras. Uno de los aciertos fundamentales de este tipo de enfoque (se refiere al análisis de las "imágenes de las mujeres" en el ámbito de la crítica feminista) ha sido el de contribuir a romper por fin con el mito de la neutralidad de las imágenes artísticas. En efecto, si hay algo que la literatura feminista ha recalcado una y otra vez es que una obra de arte no es un producto "inocente", desprovisto de carga ideológica, sino que, por el contrario, responde a los discursos dominantes en la sociedad en la que fue creada.

\section{Proyecto Mujeres en Espiral}

Este es un proyecto asociado con un sistema de justicia, perspectiva de género y pedagogías en resistencia.

Trabaja con prácticas artístico-pedagógicas y jurídicas, con el fin de favorecer el acceso a la justicia de mujeres en reclusión y la transformación de patrones culturales y de género. Asimismo, busca influir en el sistema de justicia a partir de la formación de profesionales universitarios, el litigio estratégico y la producción de conocimiento desde una perspectiva interdisciplinaria y de género (Mujeres en Espiral, 2018).

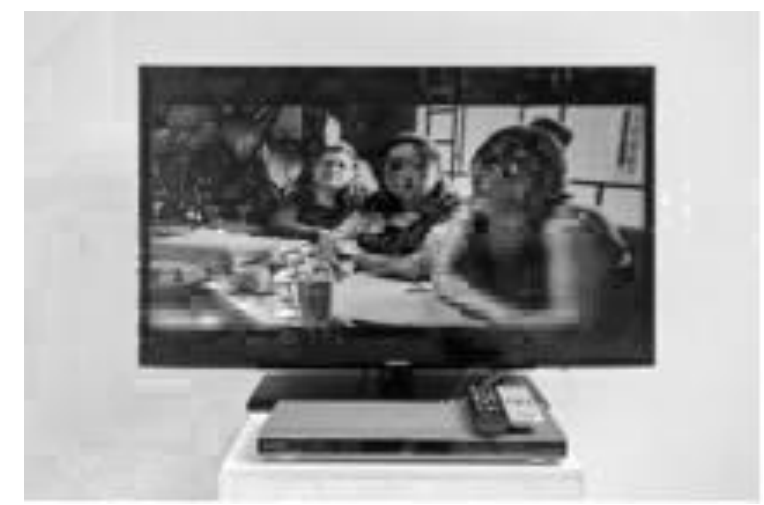

Figura 1. Cinetiquetas: La/mentada de la Llorona. Mujeres en Espiral. Fuente: fotografía de Rafael Prada (2018).

Mujeres en Espiral es un grupo de investigación constituido en 2008 en la Universidad Nacional Autónoma de México (UNAM), en el Programa Universitario de Estudios de Género (PUEG). Conforman el grupo Patricia Piñones, Rían Lozano, Zac-nicte Reyes, Yadira Cruz, Gisel Tovar, Anaid Martinez, Nictexa Ytza y Marissa Belausteguigoitia, quien lo dirige. Su trabajo evade los modos convencionales de materialización de objetos artísticos y elige construir procesos interdisciplinares de acción en contextos humanos condenados a la marginalización y la injusticia por parte de los organismos de Estado, pero también por las interpretaciones que hace la sociedad. Su metodología es construir acciones de resistencia y visibilización de las mujeres, por medio de prácticas artísticas, pedagógicas y jurídicas desde una perspectiva de género.

En el caso concreto del video La-mentada de la llorona, presentado en la exposición (ver Figura 1), el grupo genera un proceso de interrelaciones, testimonios, talleres lúdicos, acciones en el espacio público y la construcción colectiva de una memoria audiovisual. Allí, mujeres que son reclusas en la Cárcel de Ciudad de México expresan no solo las causas por las que han sido sentenciadas, sino sus sentires en el cotidiano dentro de aquellos espacios. Se escucharon sus pronunciamientos respecto a la justicia y las categorizaciones que el gobierno y la sociedad hacen de ellas, desconociendo sus derechos, su condición en desventaja y los vacíos del sistema penitenciario frente a sus situaciones particulares y las estigmatizaciones que homogenizan y naturalizan sus historias.

Para ello, estas mujeres utilizan soportes como la pintura en papel y el espacio público, a través de murales, pero también comparten sus testimonios de vida tomando parte activa en la construcción del documental. Estos recursos se ponen en contraste con comentarios que hace la gente en las calles sobre la condición de estas mujeres y especulan sobre las motivaciones que pueden haberlas llevado allí. De otra parte, se alternan participaciones de especialistas del sistema jurídico oficial y las conceptualizaciones de las investigadoras del grupo Mujeres en Espiral.

De esta forma, el trabajo artístico se asume como una construcción multidisciplinar en el contexto de la academia investigativa, y se establece como resistencia a las prácticas convencionales del arte trabajando desde los márgenes, así como desde lo que Haraway (1984) Ilama las parcialidades para la construcción del conocimiento. Esta es una perspectiva coherente con la propuesta que Lozano (2010) hace en su tesis sobre las prácticas culturales "a.normales".

Finalmente, es importante mostrar el impacto social que ha tenido el grupo Mujeres en Espiral, que ha trascendido, incluso, las fronteras mexicanas. Este informe de referencia lo hace la licenciada Hannia Novell en la revista digital Mujer es Más, en enero de 2019, en el artículo titulado "El ring de los debates: Mujeres en Espiral, una esperanza para las mujeres reclusas":

A 10 años de distancia, Mujeres en Espiral ha demostrado que tiene consolidados objetivos académicos y de creación artística. Ojo: no se trata 
de un proyecto asistencial. El Cefereso de Santa Martha se ha convertido en una extensión del campus universitario no solo para quienes están privadas de la libertad, sino para los académicos, artistas, activistas, servicios sociales, becarios, alumnos y egresados.

\section{UN PROGRAMA QUE HA TRASCENDIDO LAS REJAS.}

El año pasado, a Marisa Belausteguigoitia, académica que dio origen al proyecto, le fue otorgada la Cátedra Andrés Bello de la Universidad de Nueva York, como un reconocimiento a esta iniciativa; y en 2017, obtuvo el premio del 9. Festival de Cortometrajes Latinoamericanos Imágenes Sociales, por "CinEtiquetas: La/mentada de La Llorona", en la categoría Cortometrajes realizados por adultos mayores.

Además, también consiguió el premio del Festival Internacional de Cine de Fusagasugá, Colombia (FICFUSA), por el documental Nos pintamos solas, en las categorías de Mejor Película y Mejor Dirección.

En 2011, el Movimiento Muralistas Mexicanos les otorgó el título de muralistas honorarias por su trabajo en la creación de la obra Fuerza, Tiempo y Esperanza, los cuatro murales representativos del Cefereso de Santa Martha (Novell, 2019).

Es importante mencionar estos niveles de impacto, pues estos modos de hacer arte a veces no se toman lo suficientemente en cuenta, por parecer que se ejercen desde afuera del arte, y más desde mujeres en acción social; pero se debe más al hecho de que el arte ha quebrado las fronteras, en aras de trabajar interdisciplinarmente y con un rol claro entre arte y comunidad.

\section{Juliana Silva}

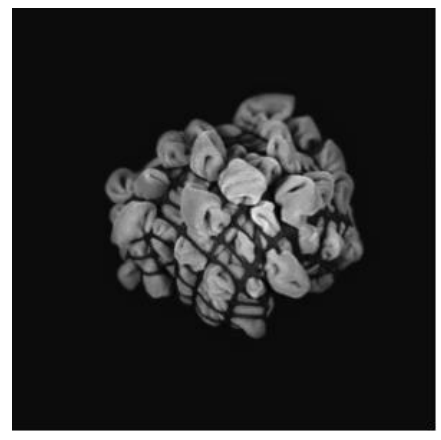

Figura 2. Specimens I, Juliana Silva (2017). Fuente: Juliana Silva (2017).
Juliana Silva es una artista colombiana que estudió en la Facultad de Bellas Artes de la Universidad Nacional Colombia, en Bogotá, y cursa una maestría en la Emily Carr University, en Vancouver, donde reside actualmente. Su obra se construye a partir de materiales cuyas cualidades tienen la capacidad de ejercer como ornamento, cuyo diseño, color y textura son evidencias de un diálogo entre personas, comunidades y espacios, cruzados por intereses que, permaneciendo aparentemente en el nivel del gusto y la decoración, son la punta visible de tensiones de intercambio político, económico y cultural.

Sobre la obra participante en la exposición Lenguas de luz, en La Galería, en Bogotá, la crítica y curadora de arte Silvia Suárez escribió:

Salvajino y Leopardo-Tigre son trabajos en los que J. S. usa patrones tomados del animal print. Ella libera estos signos sueltos del torrente de producción que los desperdiga en innumerables textiles, adornos, juguetes y prendas de vestir. Dentro de ese sistema, los vestigios de la potente voz de estos signos en el lenguaje de la naturaleza son ya casi imperceptibles, así que J. S. Ios rearticula en un juego de luz, color y texturas, en un mundo plenamente artificial. A este mundo pertenecen también sus Objetos Suntuarios, presencias a medio camino entre el objeto de lujo y un salvaje, insidioso y pequeño animal (2014).

La artista, al hablar de su obra Organismos vivos para espacios interiores, afirma que se interesa por los materiales vulgares que se producen masivamente y que imitan estéticas dominantes, como el terciopelo, el encaje, los hilos de oro, entre otros, que vienen de un legado europeo y de una cultura textil diferente. Para Juliana, muchos de estos elementos sutilmente se erigen como símbolos de poder que luego son apropiados por la cultura popular transformándolos en algo diferente (Silva, 2017).

Juliana sabe que cuando utiliza un material que emula el refinamiento y se vanagloria en lo ornamental, se está ejerciendo un acto de engaño que excita aún más la ironía. Ello, en la medida en que incluso la misma obra artística pareciera ganar en elegancia y decoro, mientras está cuestionando las relaciones de poder, banalidad y la trampa de seducción que ejercen los objetos a costa del trabajo barato de los trabajadores textiles o de mobiliarios llenos de detalles y florituras.

En este sentido, es importante recordar el artículo escrito por Adolf Loos en el que plantea: 
Los platos ornamentados son muy caros, mientras que la vajilla blanca que le gusta al hombre es barata. Este ahorra mientras el otro se endeuda. Así ocurre con naciones enteras [...]. Es conocida la situación en los oficios de talla y adorno, los sueldos criminalmente bajos que se pagan a las bordadoras y encajeras. El ornamentista ha de trabajar veinte horas para lograr los mismos ingresos de un obrero moderno que trabaje ocho horas. El ornamento encarece, por regla general, el objeto (1908).

Juliana realizó dos obras que trazaban claramente sus ambiciones conceptuales con la ornamentación y los espacios arquitectónicos. En 2005, en su trabajo de grado, realizo in situ una transformación de la fachada del edificio de la Facultad de Bellas Artes de la Universidad Nacional de Colombia, en Bogotá, poniendo elementos decorativos alusivos al pastillaje en repostería, siguiendo las líneas arquitectónicas de este edificio blanco y robusto, y llevándolo a una situación entre el ridículo, el sinsentido y el despilfarro. Esta misma estrategia la desarrollaría en 2012, en una exposición de profesores del Programa de Bellas Artes de la Universidad Industrial de Santander, cuando tomó las dos columnas centrales de la sala de exposiciones Macaregua, lisas y blancas, y las pintó del piso al techo con un color celeste y luego agregó recortes decorativos de pastillaje que, con el pasar de los días, comenzaron a derretirse poniendo de manifiesto su composición y su carácter efímero.

Estas obras evidencian su interés por lo fatuo, la vanidad, la superficialidad en la que se invierte el trabajo, con el fin de develar esas tensiones políticas que guardan los espacios oficiales, los objetos y la propia mirada expectante del observador de arte.

Hay un elemento que nos interesa mucho en la obra de Juliana, que se fortalece aún más en las últimas obras, en especial en las dos obras fotográficas presentadas en la curaduría Iconografías femeninas, y es lo relacionado con la llamada sensibilidad femenina en la historia del arte. Sus trabajos asumen de frente materiales y modos de hacer que en otros momentos de la historia podían ser calificados como parte de una sensibilidad femenina diferente en relación con el arte de los varones, representada en el ornato, la delicadeza, la suavidad y la elegancia, que para la crítica de sesgos estereotipados correspondían a la mujer y sus atributos; "la costumbre de ensalzar las virtudes de la mujer (su belleza, su distinción, su modestia...) por encima de las de la artista" (Mayayo, 2015). Juliana, precisamente, se vale de esas evaluaciones estereotipadas para hacer visible la fuerza de contenidos que pervive en el material elegido, así como en las connotaciones históricas que se han cruzado en los procesos de colonización que se enquistan soterradamente en las concreciones del diseño, la moda y los actos de la adquisición y el uso.

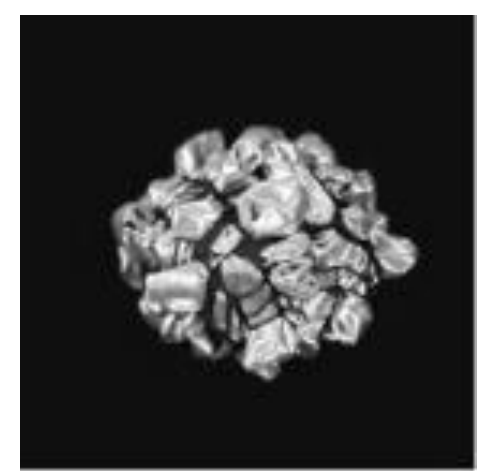

Figura 3. Specimens II, Juliana Silva (2017). Fuente: Juliana Silva (2017).

Specimens / y II son fotografías de objetos escultóricos (ver Figuras 2 y 3), una suerte de apretujamientos de telas, la una, terciopelo rojo, y la otra, un textil dorado, atrapadas en unas mallas tejidas en hilo que las contienen y les dan formas como de amebas. Dan la impresión de ser, en sí mismas, unas materializaciones absurdas que podrían, en determinado momento, reírse de lo que es, puede ser o quiere ser arte. Pero en realidad son lo que Juliana misma llama, en el contexto, sus escritos, organismos vivos, en el sentido que se proponen como artefactos activadores de relaciones de significado, valor y sentidos en lo cultural. Los textiles, con todos sus atributos, están lejos de ser objetos muertos en los circuitos en que se mueven, porque son, precisamente, contenedores de valores que definen situaciones de intercambio, estatus, poder y dominación. Ella misma gusta de hablar de las diferencias en las telas de los atuendos que solía llevar la realeza y los plebeyos en las monarquías europeas, poniendo barreras indiscutibles en los materiales de elaboración, el color y los diseños. Contrástese, por ejemplo, las telas blancas o sepias sin ornamento en la vestimenta de los plebeyos frente a las telas de seda, con finos diseños y floridas combinaciones de color, realizadas en los telares de Valencia para las realezas europeas.

En la manipulación de estos textiles la artista pone en juego dos fuerzas: la contención y el desbordamiento, que seguramente están aludiendo al cuerpo femenino desde la perspectiva de la mujer sometida a fuerzas capitalistas y misóginas de manipulación, en la medida 
en que el vestido que da forma y ornamenta el cuerpo femenino lo convierte en objeto de estatus antes que en sujeto, en una sociedad que espera de la mujer belleza y recato, algo de lo que el varón debía vanagloriarse. Aquí vale la pena recordar la función que cumplía el corsé, especialmente en los siglos XVII y XVIII, cuando se vuelve más sofisticado y complejo para moldear la figura de la mujer. A partir del análisis de esa prenda de vestir y su relación con la moda, se manifiesta aún más la relación con lo corporal desde una refracción cultural del deseo de contener y controlar el cuerpo de la mujer.

En la obra de Juliana, se puede advertir, a través de sus materiales, que estos patrones de valor simbólico perviven en la cultura contemporánea, desde perspectivas muy interesantes; por ejemplo, la imitación de materiales y joyas para facilitar su uso.

\section{María Isabel Rueda}

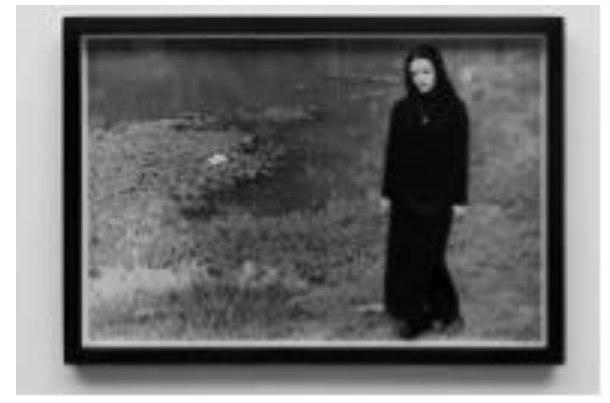

Figura 4. Vampiros en la sabana, María Isabel Rueda (2012). Fuente: Rafael Prada (2018).

María Isabel Rueda es una artista en cuya obra se aprecia un interés por lo "oscuro", los otros de la sociedad, los "seres B", como suele identificar a los que están al margen o por fuera del canon (Ochoa, 2016).

En la obra de María Isabel Rueda emerge, de entre lo oscuro, la brillantez que genera la fricción entre la noche, la naturaleza y el amor. Lo oscuro está presente siempre como una condición de fondo, como un bosque atemorizante por el que hay que pasar de todas formas. Sobre esa pantalla negra aparecerán figuras femeninas tristes pero bellas, pálidas pero radiantes, disgustadas con su siglo. También emergen, en otros planos, plantas y flores que se excitan por los cuerpos que aman. Hay en estos senderos de dibujo aves e insectos que rememoran el deseo y el dolor, la amenaza que subyace en el eros.

La artista nace en Cartagena de Indias, en el Caribe colombiano; estudia en Bogotá, en la Facultad de Bellas
Artes de la Universidad Nacional, y vuelve a instalarse en el Caribe, esta vez en Puerto Colombia, apartada un poco de las ciudades del turismo convencional y las muchedumbres.

El interés por la obra de María Isabel se enfoca sobre dos elementos en especial: los personajes góticos que aparecen en sus fotografías de formatos medianos, en blanco y negro, y la forma en la que utiliza figuras femeninas y masculinas en escenarios de prolija naturaleza en convivencia con plantas y animales. De esta forma, genera una actividad poética y simbólica de gran sensualidad plástica, así como de activación de la memoria y de los sentidos con respecto a la continua danza entre la vida y la muerte (ver Figuras 4 y 5).

Emiliano Valdés, quien fuera curador del Museo de Arte Moderno de Medellín, escribió:

María Isabel Rueda se interesó entonces por lo oculto, lo anormal y lo sobrenatural -o "supernatural"-, intereses que describe delicadamente en múltiples medios, incluida una múltiple producción de dibujos en la que el amor y la comunión con el mundo también son temas centrales. Ese interés por lo esotérico llevó a Rueda a retratar lugares, personas e historias que son oscuras solo a la luz de la idea modernista de progreso, en la cual la luz representa el símbolo del conocimiento racional (2016).

Al observar ligeramente su obra se puede, equivocadamente, dar por entendido que no se establecen relaciones con los ámbitos temáticos que leen el acontecer histórico de Colombia, perspectivas sobre las cuales ha transitado la mayoría del arte realizado en este país. Sin embargo, es su método y su abecedario de imágenes los que no se acomodan a esa tendencia en los modos de hacer tradicionales.

Inicialmente propicia un acercamiento a personas de la vida real que asumen un modo de vida que no es el de la mayoría de la población. Su comportamiento se da como un acto político que de forma anárquica mira y evalúa la indiferencia de un sistema viciado que centra su visión de la muerte, de manera miserable y descarnada, en la estrategia de la aniquilación y el olvido. Estas personas actúan, como otras tribus urbanas, desde una posición contracorriente, de arrojo y decisión por una forma de estética y de vida relacionada con lo oculto, el misterio y la desilusión por una sociedad fallida. Los han Ilamado góticos, y la interpretación puede quedarse en la superficie de la infelicidad, relacionándolos con el disgusto por 
el vampirismo; pero podría tratarse mejor de una mirada desafiante a los lugares de confort escogidos por la sociedad dominante, la aparente felicidad en el consumo y la alegría que borra del cotidiano realidades ocultas que el sistema genera sobre los individuos, en sus soledades y también en las apariencias grupales.

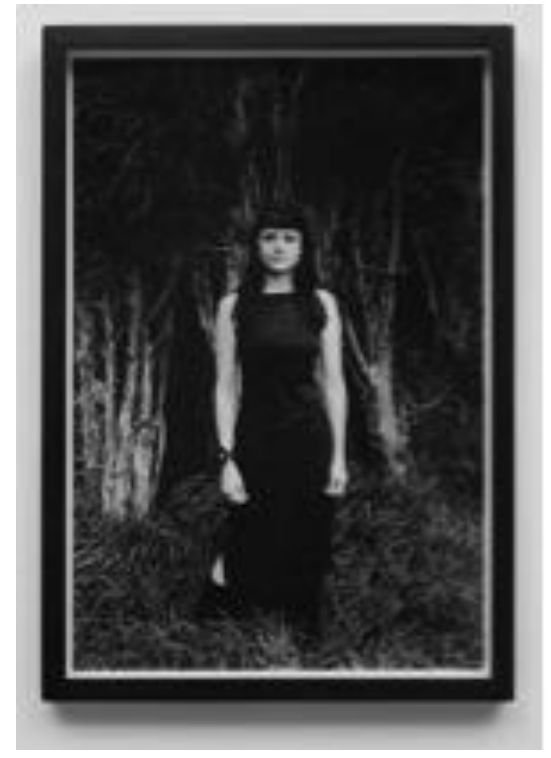

Figura 5. Vampiros en la sabana, María Isabel Rueda (2012). Fuente: Rafael Prada (2018).

Si se observa su obra desde el punto de vista de los intereses de esta tesis con respecto a las apropiaciones y usos de la figura femenina, es importante decir que parte de su producción está fundamentada en las nuevas representaciones de la figura femenina desde su relación con algunos estereotipos y reivindicaciones. Sus mujeres de Vampiros en la sabana pueden tener relaciones ancestrales con las mujeres fatales, concretamente mujeres vampiro propias de mitologías paganas; pero, en realidad, el sentido de reivindicación parte de la realidad, de los márgenes de la cultura y las inclusiones que hace el arte a través de la tenacidad investigativa de los artistas en los sustratos de la cultura urbana contemporánea y sus problemas. Aquí el reconocimiento del otro es fundamental, al igual que el rol que como artista se asume en esas representaciones.

Lipovetsky (2006), en su libro La era del vacío, deja en claro las decepciones de las nuevas individualidades frente a las fallidas instituciones del Estado, la Iglesia y la familia, que arroja a los jóvenes hacia nuevas formas de vivir en soledad o, incluso, en pequeños clanes o cofradías. Nuevas emergencias en solitario surgen por un absoluto desconcierto y decepción por las promesas del progreso, las instituciones y la ciencia. La belleza subyace en la sinceridad y lealtad consigo mismo; en lo cotidiano se ve mucho color y brillo, pero la sensibilidad profunda puede ver en blanco y negro. La sociedad contemporánea produce esas visiones de incertidumbres políticas, márgenes, migraciones $y$, por tanto, refugios en lugares inimaginables.

\section{Andrea Rey}

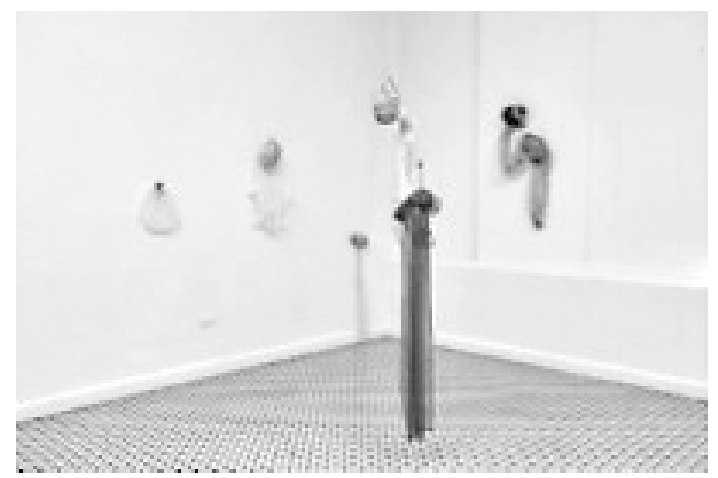

Figura 6. De encaje y piel, Andrea Rey (2017). Fuente: Rafael Prada (2018).

En 2014, en el contexto de la exposición Presentes, el filósofo Martín Camargo escribió que Andrea Rey no había dejado entonces de indagar en las posibilidades de mediación que le ofrecían determinados elementos como extensiones poéticas de su subjetividad y su cuerpo. Se refería al uso, en sus esculturas, de materiales como telas, hilos, cabellos y maderas. Pero Camargo subraya luego el giro que da Rey al "utilizar la donación erótica de la obra como metáfora de pasividad femenina, [...] como un espacio de acogida, recepción y resguardo en el cual resguardar la frágil subjetividad del espectador" (2014).

Desde comienzos del 2000, cuando inicia sus estudios en el programa de Bellas Artes de la Universidad Industrial de Santander, Colombia, Andrea muestra un interés especial por trabajar con materiales encontrados que están dentro de su contexto personal e íntimo. Pronto deja el dibujo y la pintura en su sentido tradicional y comienza a experimentar usando telas, hilos y materiales orgánicos como uñas y cabello a los que trasladaba, de todas formas, el dibujo y el color. Estas experimentaciones la diferenciaron rápidamente en el escenario artístico de Bucaramanga, ciudad donde este tipo de aproximaciones eran prácticamente nulas. La artista abre en la ciudad un nicho explorable para las nuevas generaciones, en cuanto a la investigación con materiales blandos para la escultura, y temáticamente 
en torno a los asuntos de género, en lo concerniente al cuerpo y a las llamadas "iconografías femeninas para un nuevo arte".

Al sumergirnos en su obra es inevitable rememorar a Eva Hesse y Louise Bourgeois, quienes pulen las aristas de este tipo de materializaciones y temas. Estas dos artistas ofrecen un legado maravilloso en el hacer desde la perspectiva femenina, asumiendo no solo nuevos métodos, sino también el viaje a laberintos que llevan a explorar el significado de ser mujer, desde el acallamiento histórico de la mujer en una sociedad que se construyó para reprimir esas dimensiones. En este legado expresivo se develan aspectos autobiográficos y familiares, ausencias, lo efímero, las asociaciones orgánicas, la vulnerabilidad del cuerpo y la emoción, el interés por lo psicológico, los miedos, lo confesional desde el propio cuerpo y el amor. Se evidencian así los traumas cotidianos que no se cuentan, las exploraciones con la infancia propia y también, por efecto del arte como modo de comunicación que se vuelve pública, el acto de mirar y ser mirado.

Sin duda, al apreciar las obras de Andrea, encontramos que transitamos algunos, si no muchos, de estos recodos de la creación. Reparamos en los materiales que construyen sus objetos y dan cuenta de que hay algo de cuerpo real en ellos que los aleja de los materiales y soportes inertes, porque encarnan en sí mismos algo tan sensible y apreciado como los secretos más íntimos.

Las cualidades textiles (ver Figura 6), lo membranoso, el abultamiento, el pliegue, la contención y el afloramiento de la forma orgánica, los hilos y los nudos, la textura de encaje, lo velado del nailon, lo maternal del algodón, el color rojo, el rosa, los grises y la pulcritud del blanco son códigos con los que se juega para permitir que emerjan en un lenguaje íntimo aquellas cosas que los seres humanos pocas veces aprendemos a decir. De esta forma, se puede asegurar que Andrea rescata el cuerpo de la mera mirada fisgona, y de alguna manera, con su particular lenguaje, nos insta a activar otros sentidos para la comprensión del cuerpo desde las relaciones entre lo visceral y las verdaderas emociones y relatos que se conectan a diario, en lo que podría constituir un ser real desde adentro, antes que una noción construida culturalmente desde fuera. Citemos a Luce Irigaray:

Invertir en la mirada no es tan privilegiado para las mujeres como en los hombres. Más que otros sentidos, el ojo objetiviza y enriquece. Se pone a la distancia, se mantiene a distancia. En nuestra cultura, el predominio de la mirada sobre el olfato, el gusto, el tacto y el oído ha ocasionado un empobrecimiento de las relaciones corporales. En el momento en que la mirada domina, el cuerpo pierde su materialidad (1978).

Pero ese cuerpo al que alude Andrea es un cuerpo fragmentado, no desde lo formal sino desde lo psicológico, para no sucumbir a la incapacidad del realismo en la representación que hace un cuerpo entero o partido desde la llamada "figura parcial", que algunos artistas modernos, como Rodin o Brancussi, utilizan. Por su parte, Kraus (2007), al analizar la obra de Bourgeois, afirma:

Pero otra lectura de la historia de mucha de la escultura modernista es que se localiza no tanto en el ámbito de la "figura parcial" como en el de la parte-objeto, dada su dimensión psicoanalítica como la meta de un instinto o impulso. El cuerpo del sujeto, enfocado alrededor de tantos órganos separados con sus necesidades y deseos, interactúa con el propio mundo exterior -el mundo objeto-, en términos de órganos recíprocos que habrán de satisfacer aquellas necesidades y deseos: el mundo del niño como tantos senos, bocas, vientres, penes, anos... La parte-objeto habla de la imperiosidad de los impulsos, de la rapacidad de sus exigencias, del modo en que el cuerpo puede, en el dominio de la fantasía, ser rasgado, canibalizado, despedazado.

Como conclusión, se puede decir que Andrea no solo articula un mundo autobiográfico de corporeidades y deseos que bien pueden ampliarse a nociones universales de lo femenino, sino que, a partir de su asimilación de la bruja, no de pociones mágicas sino de materialidades y saberes cercanos a la mujer, logra concretar uno de los roles más maravillosos que tiene el arte, el de poder correr el velo para dejar ver el encuentro entre lo invisible y lo visible. Esto significa dejar salir de la caja de Pandora no solo los órganos intangibles del placer y de sentires inexplicables, sino también, incluso, engendros de trapo y escenografías del secreto en las cuales nos podemos poner en escena.

\section{Juan Canales Hidalgo}

Juan Canales disfruta de las relaciones entre la imagen y las palabras, las metáforas nada explícitas, quizás sin sentido aparente. El joven practica la toma de apuntes ocasionales sobre lo cotidiano y ensoñado que convierte en pintura: (re)presentación poliédrica y bastarda de objetos y signos (Canales, 2018).

Juan Canales Hidalgo es un artista español que realizó sus estudios de maestría y doctorado en la Universidad 
Politécnica de Valencia, donde es profesor. Su principal campo de investigación ha sido el arte urbano. En las pinturas y dibujos de Juan Canales sentimos un encuentro con la memoria profunda, la invención que permanece radiante en las cosas que se actualizan en cada señal que regala el camino, solo si como caminante se logra ver futuro en cada roca y cada recodo.

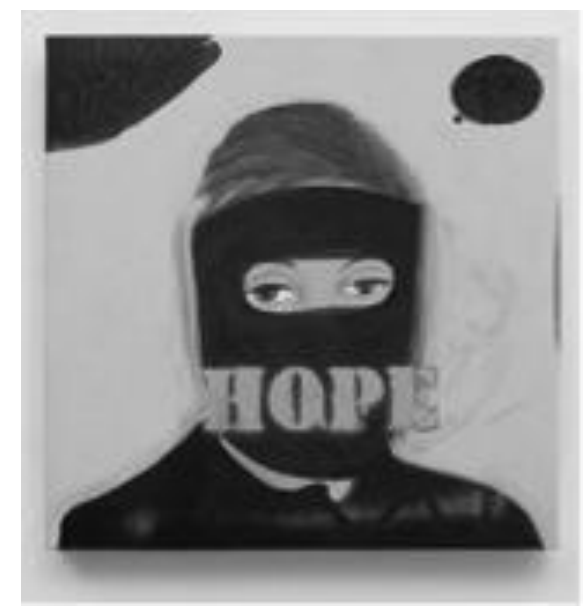

Figura 7. Ni una menos, Canales (2017). Fuente: Rafael Prada (2018).

Percibimos en sus trabajos una concurrencia con la realidad en un estado que celebra su existencia, la comunión de la segunda oportunidad que revela su forma, su luz y su elemental verdad, elementos suficientes que permiten al espectador comprometido develar la poética que reside allí, sin remedio, en el umbral de la realidad y la pintura.

Un palito de árbol desprendido; una roca cuyo silencio canta una historia milenaria y su belleza en sus vetas grises y blancas, su volumen y su brillo logrado pacientemente; una planta moribunda con aura de azúcar rosa, una tienda de campaña que sobre fondo naranjado sintetiza todos los refugios y los viajes. Incluso, todas aquellas cosas que solas y en dibujos de marcadores podrían semejar mamarrachos, se aparecen como coladas en el escenario, no reclamando sino evidenciando su esplendor. Es un caso en que subyace y emerge, en muy buen sentido, una sensibilidad femenina respecto al mundo, sin intereses especiales de grandeza, más bien con el coraje de mirar desinteresadamente la poesía que emana de entre las propiedades más elementales y toscas de la pintura y la aparición de actores que son cosas al margen. Es como reconocer que todo paisaje tiene rendijas, accesos no solo a la memoria sino a universos latentes donde se activan nuestros silencios y olvidos. Se encuentra en su obra pintura y conocimiento sustentados en parcialidad y sencillez, algo que revalúa los intentos hegemónicos por totalidades, verdades y protagonismos arrogantes.

En las pinturas que están en la exposición, Ella y Ni una menos, se plantean posturas aparentemente diferentes. En Ella vemos una pintura extraña en la cual aparece su esposa, en un pulso que confronta lo privado y lo público; es más, es importante saber que se parte de una fotografía, registro tal vez de una circunstancia propia en los desplazamientos de sus asuntos cotidianos (ver Figura 7).

Aunque todas las imágenes se dejan leer, la pintura se torna un callejón de difícil acceso, pone en forcejeo las señales: la bermuda amarilla en que parecen estamparse geografías y geometrías, el rostro cortado ocultando sus ojos y un trazo de aerosol rojo que parece cohibir su paso o prevenirle de algo fuera del cuadro. El relato sigue su construcción a medias, la figura presurosa, sus pechos expuestos e iluminados por la luz de su destino, sobre los cuales pende lo que parece ser un amuleto o un diablillo. El suficiente gesto de complacencia de su boca, la disponibilidad al viaje que se evidencia en la forma en que agarra su mochila y su blusa, todo sigue la lógica del fragmento como matriz para imaginar historias. De otra parte, en lo formal, el encuentro de los códigos de la pintura de caballete con el gesto del aerosol, el blanco y negro, el color medido, lo autobiográfico, en fin, ese relato furtivo en torno a la figura femenina que sabe reservarse algo.

Por el contrario, en Ni una menos, aun sabiendo que también es su esposa Ñaja, esto no se evidencia, pues el ocultamiento está explícito en una mujer enmascarada, y la figura puede ser relacionada con toda una población y con una intencionalidad concreta. Como el mismo Juan dice: "Ñaja deviene más bien en símbolo universal, arquetipo que pide el NO sufrir". Su mirada en actitud desafiante, triste, pero en lucha y dispuesta a todo, una imagen que puede fácilmente verse como bastión de militancia. La transparencia comunicativa de la imagen es seductora, tajante y robusta.

Pensar la mujer como geografía es frecuente en la poética y la vida diaria. Es un intento por entender sus latitudes, temperaturas y misteriosa sensación de viaje permanente, un intento de la conciencia por comprender la naturaleza amenazante de la mujer entre la permanencia y la ensoñación. De ahí lo misterioso de la imagen de la mujer que lee, sobre la cual, recientemente, se ha especulado en algunos análisis de pinturas, una mujer que mira al infinito, peligrosa para el patriarcado. 


\section{Diana Bama}

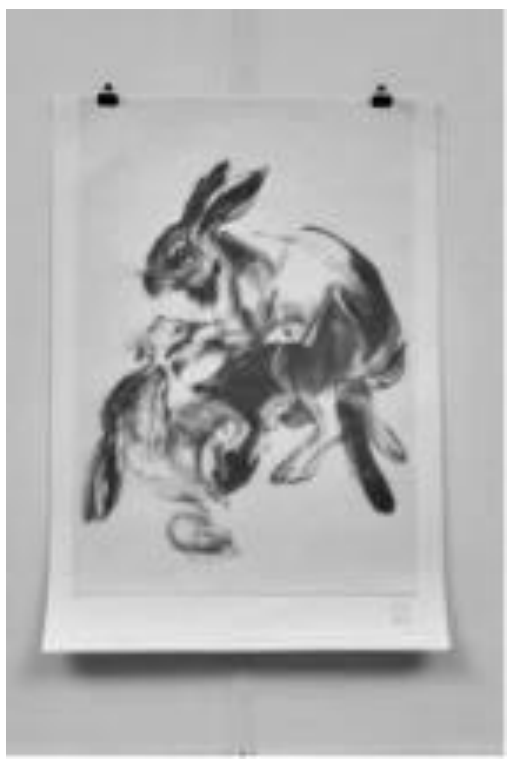

Figura 8. Perder el miedo, Diana Bama (2018). Fuente: Rafael Prada (2018).

Diana Bama es una artista española que reside y trabaja en Ciudad de México. Ha desarrollado su formación académica entre Valencia y Ciudad de México. El autor conoció a Diana por referencia de un artista español, Juan Canales, en México, en octubre de 2017, cuando realizó una estancia de investigación en la UNAM. Allí se pudo apreciar el trabajo de Diana, en murales en los que aparece reiteradamente la figura de la coneja, precisamente en una de sus elaboraciones in situ en una azotea de un antiguo edificio en el centro de Ciudad de México, y al mismo tiempo se pudo observar sus dibujos de formato intimista.

Amablemente Diana accedió a dialogar en el formato de entrevista; algunas de las preguntas y respuestas se exponen a continuación, y dejan claro de qué va su trabajo y su opinión sobre su residencia en México:

Germán Toloza (G. T.): Diana, tu posición como persona y como artista está relacionada con el movimiento que han llamado ecofeminismo. ¿Puedes, por favor, definir cómo ves esa postura como artista en el contexto que vivimos actualmente?

Diana Bama (D. B.): Llevo una de las teorías del ecofeminismo a mi campo, el del arte, y en este caso podríamos Ilamarlo arte urbano, no solo porque se sitúa en un espacio público, sino porque necesita de este para completar su significado. Me he centrado en la idea del cuidado y el respeto no solo entre las personas (como pretende el feminismo), también ampliando su mirada hacia los animales (una parte del ecofeminismo) y generando un vínculo entre el animal y la mujer. Siento que es muy complicado hacer un diagnóstico del contexto actual en el que vivimos, ya que hay demasiados factores de los que podríamos hablar, pero haciendo un paneo rápido, siento que sí existe un movimiento hacia el empoderamiento de la mujer, creo que todavía falta mucho por trabajar y trabajarnos, pero creo que sí hay un interés mayor en el feminismo y en buscar herramientas y recursos para generar iniciativas en las que existe una ideología feminista. Por otro lado, siento que en el aspecto animal es un poco diferente, en el que estamos todavía muy lejos de alcanzar un respeto hacia las otras especies.

G. T.: He visto que haces dibujos en pequeño formato, pero creo que la forma de materializar tu obra tiene especial vínculo, o quizás debo decir vínculo definitivo, con la realización de pinturas murales. ¿En qué momento y por qué decides seguir esta ruta o modo de hacer?

D. B.: Sí, siempre he trabajado en pequeño formato, por la comodidad que ello implica, tanto económica como a la hora de transportar las obras. Pero también tuve siempre ese interés por las intervenciones en los espacios públicos, solo que por varios motivos nunca me di la oportunidad, hasta llegar a la universidad, donde cursé algunas materias que estaban relacionadas con el arte y el entorno. A partir de ese momento me di cuenta de que era algo que me estimulaba a generar otras cosas, y en 2014 empecé a convertirlo en una parte más de mi trabajo. Ese mismo año me concedieron una beca de creación en México, y desde entonces no he dejado de pintar e intervenir paredes.

G. T.: ¿Qué opinión te merece la labor de los artistas que hacen arte urbano, en espacios marginales, espacios no oficiales, espacios con connotaciones simbólicas especiales, confrontado esto con el arte que se destina a los espacios tradicionales de exhibición, museos, galerías, etc.?

D. B.: Para mí es muy importante que existan ese tipo de espacios alternativos, y que lugares que no estén destinados a mostrar arte se reconviertan. Pero también esto puede ser un arma de doble filo; ya ha pasado en varias ocasiones que los lugares "marginales" se han empezado a "gentrificar" justo por ser lugares en los que ha comenzado a existir un movimiento cultural; eso no quiere decir que esté en contra ni mucho menos, pero creo que hay que ser críticos y observar cómo están repercutiendo nuestras acciones en los lugares donde se establecen. 
G. T.: Haces uso reiterado de la imagen de la coneja, si no estoy mal con una clara o frecuente sugerencia de preñez, personaje animal que exploras utilizando diferentes elementos compositivos, en especial de la naturaleza, que sugieren los sesgos temáticos o los relatos. ¿Nos cuentas algo al respecto, por favor? (ver Figura 8).

D. B.: La idea de las conejas surge a partir de una exploración gráfica de intentar generar imágenes en las que se creara un vínculo formal entre la mujer y el animal, persiguiendo esta idea de que estamos hechos de la misma materia. Al principio eran diferentes animales y poco a poco fui reduciéndolo a la coneja, por diferentes motivos. Creo que formalmente el conejo tiene una anatomía que funciona muy bien mezclándola con la de la mujer, pero sobre todo por las ideas o connotaciones que el animal tiene. He partido de la idea de que en España a la vulva se le llama conejo, he pasado por toda la cuestión sexual que va de la mano de los conejos, pues se ha vinculado su actividad sexual con la promiscuidad. Por otro lado, hay que aclarar que estas conejas son medio mujeres, de ahí que tengan manitas, pechos y vagina; esto no implica que están gestando, simplemente tienen pechos.

G. T.: ¿De qué manera te relacionas, o cuál es tu posición frente a los feminismos y de cara a la realidad diaria?

D. B.: Sí me considero feminista, aunque a veces todavía me salen algunas cosas que no lo son. Intento trabajar en ello cuando así me sucede, identificarlo, buscar el motivo y sacarlo de mí para no volver a repetirlo en el futuro.

Creo que hubo un tiempo en el que no me gustaban tanto las "etiquetas", y bueno, en la actualidad me sigue sucediendo, entonces no es algo que vaya quizás en mi carta de presentación. Pero si me preguntan no me da vergüenza decirlo o afirmar que sí me siento feminista, considero que es lo más lógico, no puedo ser mujer y no ser feminista.

En mi caso, dentro de los feminismos creo que rescato esa parte del ecofeminismo en la que los animales tienen cabida, donde se busca una equidad también hacia las otras especies. Está muy relacionada la opresión de la mujer con la del animal, tanto que dentro de la explotación animal las hembras suelen ser las más perjudicadas.

G. T.: ¿Contrastarías de alguna forma la imagen y la situación de la mujer en España, tu país de origen, con la de la mujer en México? Antepongo la imagen también porque me interesan las representaciones que se hacen de la mujer. Bueno, y si hay alguna situación en especial que quieras subrayar del cotidiano de la mujer en México; por poner un ejemplo, los vagones para la mujer en el metro.
D. B.: Esta pregunta es muy complicada, porque conforme voy hablando, voy recordando o encontrando momentos en los que te das cuenta de cómo es vivir siendo mujer en una ciudad como México. Hace unos días hablaba con unos amigos y me preguntaron qué era lo que menos me gustaba de los mexicanos, y enseguida tuve mi respuesta: el machismo que hay, creo que es lo que menos me gusta y lo que peor llevo. Sí hay mucha diferencia entre España y México en ese aspecto. En España hay mucho que trabajar todavía y falta mucho camino por recorrer, pero ya se entiende que hay cosas que no pueden ser factibles y la sociedad no acepta. Para mí es un poco la idea de que en España tenemos un "machismo light" o los micromachismos, con los que hay que tener cuidado, porque creemos que estamos en una sociedad superequitativa, en la que el machismo ya se ha erradicado; pero nada que ver, sigue existiendo, y hay que seguir haciéndolo visible.

Mientras que en México hay una violencia hacia la mujer a una escala muchísimo mayor, y no se intenta camuflar o disimular, parece que aquí ejercer el machismo es algo positivo en algunos ambientes. En México la violencia hacia la mujer por el hecho de ser mujer es diaria. Desde los feminicidios que se cometen cada día en el país, pasando por el acoso familiar, el acoso callejero...

\section{G. T.: ¿Cómo te sientes como mujer y artista en México?}

D. B.: Me gusta poder desarrollar mi trabajo aquí; México me ha brindado muchas oportunidades, tanto de formación académica como experiencia personal. Intento hacer las cosas de la mejor forma que sé y puedo. Me gusta pensar en la idea de poner mi granito de arena en una lucha que todavía tiene un largo recorrido, pero en cuyo camino te encuentras personas lindas que tienen formas de pensar y ver que te aportan nuevas ideas y te ayudan a conformar nuevos pensamientos para seguir creciendo.

Se puede apreciar que Diana ofrece luces que dejan muy en claro su función como artista, como una activista del ecofeminismo, de manera simbólica, desde la representación animal. Esto lo hace llevando la pintura al espacio urbano, donde estos temas sobre la mujer y la naturaleza no son muy comunes. De otra parte, nos ofreció argumentos contrastantes sobre el tema de la mujer y los machismos entre su país de origen, España, y México, país donde vive y desarrolla sus proyectos.

\section{Laura Ribero}

Laura Ribero estudió en la Facultad de Bellas Artes de la Universidad Jorge Tadeo Lozano, en Bogotá; luego, realizó 
maestría y doctorado en la Universidad de Barcelona. Actualmente vive y trabaja en Brasil.

La primera impresión al apreciar las fotografías de Laura es una suerte de suspensión de incertidumbre, marcada sobre todo por el ensimismamiento del personaje -que regularmente es ella misma- y el lugar en que se escenifica. Sin embargo, en esa conjunción del personaje y el lugar, es fácil pensar que no es ella misma, precisamente por el carácter dramático de la escenografía, que puede ser las dos cosas: encontrada y planificada. Asumir en el proceso no ser ella misma no implica una renuncia a la dimensión autobiográfica, sino una conciencia de proyectar su experiencia a una problemática más amplia social y culturalmente.

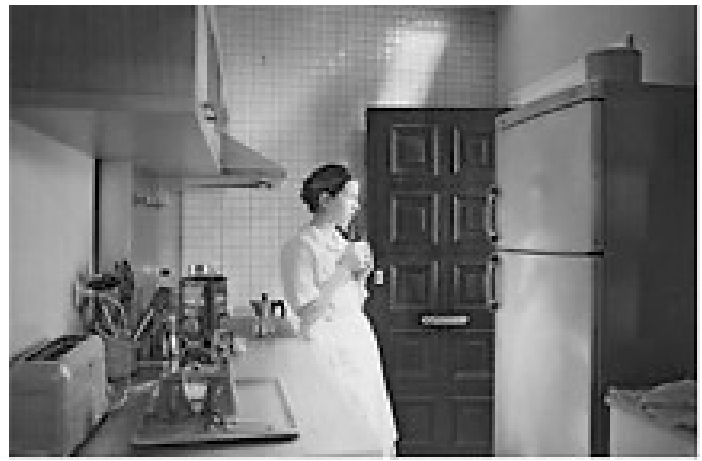

Figura 9. Electrodoméstica, Laura Ribero (2003/2004). Fuente: Laura Ribero.

Dentro de la estructura formal de las fotografías hay algunos elementos comunes, planos arquitectónicos que aportan silencio al lugar, una matemática visual en la cual cada objeto o cada accidente lineal dialoga simbólicamente con esa entrega reflexiva del personaje en soledad. Ese diálogo compositivo de los elementos nos habla de lugares transitorios, una demolición, una cafetería, un teatro, la calle o la cocina, en la que el personaje mira hacia adentro o quizás a la distancia, a través de un artefacto de memoria que puede ser una taza de café, un libro, una naranja, una lámpara de noche o un elemento más habitual en la literatura y la pintura, como una ventana (ver Figura 9). Si permitimos que esos elementos narrativos cobren resonancia autobiográfica en los recorridos que Laura ha emprendido, entonces se podrán abarcar relatos políticamente vigentes en relación con las migraciones. Desembarcar en otras culturas significa confrontar al otro y ser leído como el extranjero, y esto insta a mirarse a sí mismo en el trasunto de identidad. Garzón (2010), en su texto crítico, lo resume muy bien a partir de dos imágenes:
La aparente normalidad de los retratos - una chica de limpieza tomando un café (Electrodoméstica, 2003), u otra con el oído apoyado en un muro de la calle (De la serie Arriving, 2006, 2007)- esconde un análisis social que toca temas como la inmigración, la identidad y los roles asumidos (2010).

Pero interesa sobremanera que sea la imagen de la mujer la que aparece en sus fotografías, y en especial ella misma (Laura), que quiere verse reflejada en sí misma. Weinzierl (2011) subraya en su obra la presencia del motivo de las vanitas, el mise en abyme, la imagen que se contiene a sí misma a través de espejos y autorreflejos que plantean la fugacidad, $y$, al tiempo, lo infinito de la existencia, como algo sustancial en la condición de ser nómada y nostálgico. En este punto, es importante citar a Dijkstra (1998), quien, al desarrollar el misterio del espejo de Venus, plantea que la mujer, habiendo vivido entre mujeres, vivió sola, completamente autocontenida, miró a otras mujeres y otras mujeres la miraron a ella, haciendo énfasis en esa capacidad de verse a sí misma en el mundo y ver el mundo a través de su reflejo.

Verse a sí misma era su único dominio de la realidad: si ella fue el espejo de la naturaleza, luego el agua, el espejo natural, fue la fuente de su impersonal, autocontenida identidad. Para evitar la pérdida de sí misma, tenía que reafirmarse continuamente de su existencia mirándose en ese espejo natural -la fuente de su ser, por así decirlo-, el agua de la que, como Venus, había venido y, a la que, como Ofelia, estaba destinada a regresar (Dijkstra, 1988).

En sus fotografías Laura asume una posición romántica y también política en lo referente a la mujer, la profundidad en su dimensión como individuo y sus roles frente a los bordes y los mecanismos de poder que se sitúan en las categorías sociales y también en las estructuras políticas y culturales.

\section{Juan Carlos Domingo}

Artista de Teruel, España, doctor de la Universidad Politécnica de Valencia, donde es profesor y miembro del Centro de Investigación Arte y Entorno.

Las obras de dibujo y escultura de Juan Carlos Domingo nos sugieren, en primera instancia, la cohabitación entre la abstracción y la emergencia de lo reconocible, en una apacible relación entre lo etéreo y la materialidad invitada. De otra forma podría interpretarse como que la sustancia se deja arrebatar por la persistencia de la memoria. Un volumen transita entre el mundo vegetal y el cuerpo humano, o, a veces, centellea la presencia 
de algún animal, como en Ángel, Unicornio en Lisboa, Trampolín o Tronco, cactus y abrazo, hablando de sus esculturas. En el dibujo presentado en la exposición, Umbral (2017) (ver Figura 10), lo mencionado se hace completamente latente en lo que interpretamos como la imagen de alguna mujer sagrada que se expande entre la abstracción de la representación y la conciencia del espectador que conecta con una realidad temporal y espacial específica. Un manto cubre su cabeza y su cuerpo, de forma que revela atributos corporales femeninos, y la actitud de sus manos señala una suerte de ofrecimiento desde la espiritualidad. Cuerpo oscuro y cuerpo luminoso se conectan. Sin embargo, consideramos que aquí la figura de la mujer se presenta no desde una definición que se interese por una ubicación en el género, sino como una personificación universal de la mujer, del acto de creación, del mundo de las ideas y de la relativización de nuestras conjeturas para definir las dualidades entre lo real y lo imaginario, o lo falso y lo verdadero, y así indefinidamente para poder ser aplicado a cada uno de nuestros juicios de ubicación: lo científico y lo sobrenatural, lo malo y lo bueno, lo aprehensible y lo fugitivo.

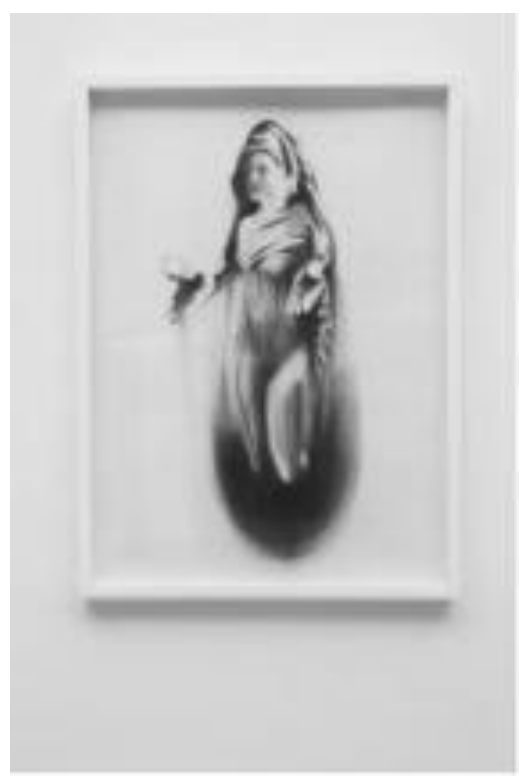

Figura 10. Umbral, Juan Carlos Domingo (2017). Fuente: Rafael Prada (2018).

Por su parte, Juan Carlos expresa sobre la obra Umbral:

Parece asumido que el ser y el parecer son dos posiciones enfrentadas. Si la primera se asocia a lo sustancial y lo verdadero, la segunda lo hace con lo superficial y engañoso. Sin embargo, y al menos para mí, sus límites carecen de tal nitidez. Ambos comparten un lugar común que imaginamos como una amplia zona de sombra.

\section{Nadia Granados, la Fulminante}

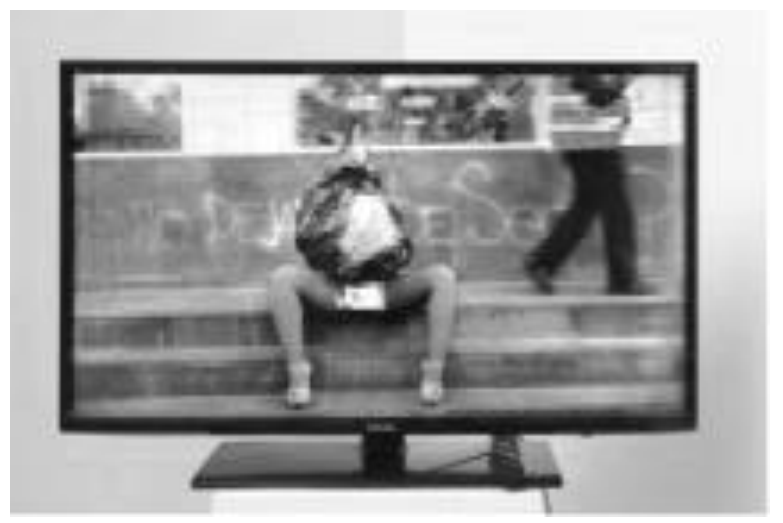

Figura 11. Carro limpio, conciencia sucia, Nadia Granados, (2013). Fuente: Rafael Prada (2018).

Nadia Granados se asume a sí misma de forma integral en el ámbito artístico y en la vida cotidiana, no solo desde las emociones, preocupaciones y filiaciones propias como individuo y como mujer, sino como una pantalla de refracción y activación política de un cuerpo social integrado por mujeres que son víctimas en un escenario contemporáneo manipulado por sesgos machistas desde todos los ámbitos. En ese escenario, las mujeres son cosificadas, abordadas y apropiadas desde intereses sexistas, y también violentadas desde lo jurídico. Nadia se apropia de los relatos cotidianos que aparentan ser normalizados, que, traducidos en acciones performáticas en vivo y en videoperformances para los mass media, se convierten en mecanismos detonantes para el activismo político (ver Figura 11).

La artista es clara y enfática sobre su postura feminista de frente a la institucionalidad patriarcal, desde el formato de expresión simbólica y política que ofrece su propio cuerpo. En un fragmento de un comentario de prensa que hace Manuela Saldarriaga para el periódico El Espectador, en el contexto de su participación en el Museo de Antioquia en 2017, expresa:

Contra el terrorismo de Estado, contra el mal gobierno, contra la impunidad, contra los sistemas de representación dominados por el heteropatriarcado, contra el discurso endémico de lo que se entiende por ser mujer, contra la violencia y contra todo pronóstico. Son estos los caminos recurrentes en la obra de la artista colombiana Nadia Granados. Como herramienta tiene el cuerpo. Empezó con la 
escultura y le hizo falta el movimiento. El cuerpo: "Lo más cercano y tangible para acercarse al mundo". Y un cuerpo femenino, además. Pero no es el cuerpo en carne, hueso y savia-sangre; es el cuerpo como receptor oprimido. "Quienes nacemos con vagina tenemos aprendizajes más nocivos implícitos en la cultura de masas que quienes nacen con pene" (Saldarriaga, 2017).

Estos relatos provienen de los diferentes repertorios del entretenimiento, de los ritos populares y también de la escena política, de manera que tanto las letras de las canciones, las conductas y estéticas pseudonarco de ciertos estratos, los modos de manipulación en el amor, las leyes contra el aborto y la violencia de género se convierten en artefactos de alto impacto para La fulminante, en diferentes escenarios culturales que enfrentan la doble moral, la misoginia y las violencias agazapadas.

Respecto a su propio accionar, Nadia expresa:

Me interesa la intervención en espacio público, por la cercanía que puedo llegar a tener con un espectador accidental, no interesado en las artes visuales, al mismo tiempo que me permite experimentar con $\mathrm{mi}$ obra plástica sin recurrir a ningún tipo de mediación institucional para realizarla, sobre todo porque cuando se trata de performance usualmente los soportes como festivales o muestras no ofrecen a los artistas nada más que la posibilidad de ser incluidos en una programación.

Frente a esto, me parece mucho mejor generar acciones independientes y permanentes que no estén asociadas a ningún tipo de institución artística, que solo dependan de mi posibilidad de hacer y quizás vincularlas a actividades de denuncia impulsadas por la sociedad civil.

Por otro lado, la idea del cuerpo como herramienta de comunicación alternativa está cargada de un gran potencial, porque el cuerpo es utilizado también para transmitir constantes discursos de violencia en espacios públicos y mediáticos (descuartizados, embolsados, fotos de cadáveres, etc.); de la misma manera, por medio de la performance podemos generar imágenes que cuestionen estas violencias naturalizadas atravesándonos en la calle a espectadores ocasionales.

\section{Leonardo Caballero Piza}

Leonardo Caballero Piza estudió Historia y Bellas Artes en la Universidad Industrial de Santander; luego, realizó una maestría en la Universidad de Minas Gerais, en Brasil.

Su trabajo, y en especial sus dibujos, se consolidan a partir de la interpretación que hace de las imágenes de reinas fotografiadas en diferentes situaciones, en sus sesiones de maquillaje, en sus salidas a pasarela y sus retratos, entre otras circunstancias; un mundo que regularmente asociamos a la idea consumista de la belleza. El asunto es que Leonardo lee comportamientos mediante la disección de la forma, el color y el dibujo, desnuda un mundo en el cual la pose deja entrever un estado de estupidez y extravío en la vanidad y el anhelo de aparición en el escenario del fatuo protagonismo (ver Figura 12).

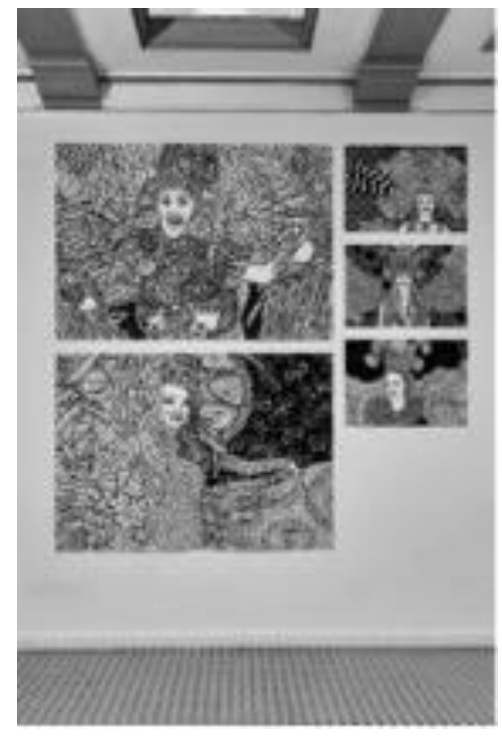

Figura 12. Wearing their national costumes, Leonardo Caballero Piza (2016). Fuente: Rafael Prada (2018).

Los recursos clave son un color asordinado que crea gamas inusuales, un dibujo tajante que consolida la forma y el fragmento como parte de un entramado que relaciona el bordado y los decorados de indumentarias y accesorios, y una controlada deformación del gesto que lleva hasta un punto de la fealdad del rostro que cita el ridículo para poner en escena una parodia que, ya en términos de estética, se ensalza en la belleza pasada por el tamiz del ojo crítico.

Leonardo ha sabido llevar con disciplina un proceso riguroso de exploración de la escena pictórica, a partir de un tema que le brinda con acierto los elementos que suma de forma sencilla para crear el relato necesario, a veces exceso en el detalle para sugerir filigrana, a veces con la simplicidad del plano del color 
y el trazo que delimita, pero lo cierto es que logra detenerse en un punto que nos devela una atmósfera en la que coexiste en arrebato de la pose pero también la ingenuidad sorprendida por la toma fotográfica y ajustada con el dejo irónico y burlesco del artista.

En algunos trabajos, prefiere dejar de lado el peso del bastidor y el color. Confía en la capacidad de la línea que se suma rica en forma y detalle sobre la calidad de la hoja de papel en blanco y a la manera en que se instala el afiche en el muro callejero. Empapela para tomarse el espacio de manera simple y económica, de forma que logra una transparencia en la idea y deja al descubierto la belleza y asertividad del dibujo.

\section{Conclusiones}

A lo largo de la historia del arte, las representaciones de la mujer han ido sufriendo transformaciones significativas, idealizaciones de miradas patriarcales sobre el desnudo femenino y manipulaciones simbólicas de estereotipos sobre la mujer que se han instaurado en los imaginarios de los artistas hasta bien avanzado el siglo XX. Este proceso ha llevado a la recuperación de espacios y modos de representación por parte de las mujeres, en los cuales se replantea la visión de estas abriendo horizontes, incluso, para nuevas lecturas de la historia y la crítica del arte. En ese sentido, los artistas en general, sin distinciones de género, han entrado en nuevas interpretaciones de las iconografías femeninas.

La curaduría Iconografías femeninas, conformada por artistas de diferentes generaciones de España, México y Colombia, ha permitido visibilizar modos diversos de representación del tema de la mujer, que utilizan todo tipo de técnicas, desde las más tradicionales hasta las experimentaciones con arte de acción, video y nuevas pedagogías; sin dejar de lado temas que, a través de diferentes problemas, convergen en la preocupación por generar nuevos enfoques y sensibilidades sobre las mujeres.

Dentro de la gama de propuestas de los artistas se perfilan algunos ejes temáticos que convergen entre sí, como las miradas autobiográficas que enriquecen perspectivas sobre las individualidades y las autoidentidades; las preocupaciones y alarmas sobre las formas de violencia política y social sobre las mujeres; las relaciones simbólicas de los materiales con respecto a lo femenino y la cultura; la búsqueda de relaciones urgentes entre arte, naturaleza y género; las experimentaciones estéticas en torno a representaciones entre realidad, imaginación y filosofía, entre otros.
De modo general, sus trabajos actúan como detonantes en la formación de nuevas generaciones de artistas y públicos más conscientes de la urgencia de cambios de paradigmas en la deplorable escena contemporánea de masacres migratorias, violencias normalizadas de género, atentados contra la naturaleza, empoderamientos de la corrupción y profundizaciones de las crisis individuales de identidad.

Hay en sus obras un talante de denuncia y defensa del respeto y la igualdad de derechos de la mujer, así como una postura que explora las múltiples sensibilidades que permanecían ocultas en el mundo de la mujer.

\section{Referencias}

Bama, D. (2018). Perder el miedo [Pintura]. Rafael Prada (Fotógrafo).

Berger, J. (2016). Modos de ver. Barcelona: GG.

Braidotti, R. (2015). Lo posthumano. Barcelona: Gedisa.

Caballero, L. (2016). Wearing their national custumes [Dibujo e impresión digital]. Rafael Prada (Fotógrafo). Camargo, M. (2014). Presentes 2014. Recuperado el 26 de mayo de 2019, de andreareysandoval.blogspot.com

Canales, J. (2017). Ni una menos [Pintura]. Rafael Prada (Fotógrafo).

Canales, J. (2018). Juan Canales \#MAL. Memoria de una pelea. Valencia. Espacio Colector.

Chicago, J. \& Schapiro, M. (1973). Female Imagery. Womanspace Journal, (1).

Dijkstra, B. (1988). Idols of Perversity, The mirror of Venus. Oxford: Oxford University Press.

Domingo, J. (2017). Umbral [Dibujo]. Rafael Prada (Fotógrafo).

Garzón, E. (2010). Laura Ribero: Fotografía entre líneas. EXIT Express Magazine (53), Madrid. 58

Granados, N. (2013). Carro limpio conciencia sucia [Performance]. Rafael Prada (Fotógrafo).

Haraway, D. (1984). Manifiesto Cíborg. El sueño irónico de un lenguaje común para las mujeres en el circuito integrado. Recuperado de https://xenero.uvigo.es/ profesorado/beatriz_suarez/ciborg.pdf

Hustvedt, S. (2017). La mujer que mira a los hombres que mira a las mujeres. Ensayos sobre feminismo, arte y ciencia. Barcelona: Planeta.

Kraus, R. (2007). El retrato de la artista como filete. En Cordero, K. \& Sáenz, I. (Comp.), Crítica feminista en la teoría e historia del arte. México D. F.: Universidad Iberoamericana, Universidad Nacional Autónoma de México.

Lipovetsky, G. (2006). La era del vacío. Ensayos sobre el individualismo contemporáneo. Barcelona: Anagrama.

Loos, A. (1908). Ornamento y delito. Recuperado de www. tecnne.com 
Lozano, R. (2010). Prácticas culturales a-normales, un ensayo alter-mundializador. Ciudad de México: Universidad Nacional Autónoma de México.

Mayayo, P. (2015). Historias de mujeres, historias del arte. Madrid: Ensayos de Arte Cátedra.

Mayayo, P. (2018). Imaginando nuevas genealogías. Una mirada feminista a la historiografía del arte español contemporáneo. Museo de Arte Contemporáneo de Castilla y León.

Mujeres en Espiral. Cinetiquetas. La/mentada de la Ilorona. Recuperado 24 de septiembre de 2018, de mujeresenespiral.com

Mulvey, L. (2007). El placer visual y el cine narrativo. Cordero, K. \& Sáenz, I. (comp.). Crítica feminista en la teoría e historia del arte. México D. F.: Universidad Iberoamericana, Universidad Nacional Autónoma de México.

Nead, L. (1992). El desnudo femenino. Arte, obscenidad y sexualidad. Madrid: Tecnos.

Novell, H. (2019). El ring de los debates: Mujeres en Espiral, una esperanza para las mujeres reclusas. Revista Mujer es Más, en enero de 2019. Recuperado el 30 de mayo de 2019, en http://mujeresmas.mx/2019/01/22/el-ringde-los-debates-mujeres-en-espiral-una-esperanzapara-mujeres-reclusas/

Ochoa, U. (2016). María Isabel Rueda: Oscuro diario. Recuperado 26 de mayo de 2019 de Artishockrevista. com párrafo 2.

Panofsky, E. (1972). Estudios sobre Iconología. Madrid: Alianza.

Pollock, G. (2013). Visión y diferencia. Feminismo, feminidad e historias del arte. Buenos Aires: Fiordo.

Rey, A. (2017). De encaje y piel [Instalación]. Rafael Prada (Fotógrafo).

Ribero, L. (2003/2004). Electrodoméstica [Fotografía]. Laura Ribero (Artista).

Rueda, M. (2003). Vampiros en la Sabana [Fotografía]. Rafael Prada (Fotógrafo).

Saldarriaga, M. (2017). Nadia Granados: Colombia no menstrua hasta que se desangre. Periódico El Espectador, Cultura, 21 de abril de 2017. Recuperado el 30 de mayo de 2019 en https://www.elespectador. $\mathrm{com} /$ noticias/cultura/nadia-granados-colombia-nomenstrua-aunque-se-desangre-articulo-690306

Silva, J. (2017). Specimens I. [Fotografía]. Juliana Silva (Artista).

Suárez, S. (2014). Lenguas de Luz. La Galería, Arte Contemporáneo. La-galeria.com.co

Ulrich, H. (2009). La curaduría, un proceso de investigación y metodología. A propósito del texto: *When Attitudes Become Form, de Harald Szeemann. Arte y Curaduría, p. 3. Recuperado el 26 de mayo de 2019, de http:// salonkritik.net

Valdés, E. (2016). Oscuro Diario: Museo de Arte Moderno de Medellín. Recuperado el 26 de mayo de 2019 de mariaisabelrueda.wixsite.com

Weinzierl, C. (February, 2011). Vanitas or the masks of a Creative Development I. EIKON International Magazine for Photography and Media Art. (73). Viena, Austria. Recuperado de http://www.eikon.at 